\title{
Toxicity Assessment, Evaluation of Antioxidant and Hepatoprotective Activity on Cordia obliqua Fruit Extracts
}

\author{
G Tharun ${ }^{1, *}$, S Sivakrishnan ${ }^{2}$, JVC Sharma ${ }^{3}$
}

\section{G Tharun ${ }^{1, *}$, S Sivakrishnan ${ }^{2}$, JVC Sharma ${ }^{3}$}

'PhD Research Scholar of Department of Pharmacy, Annamalai University, Chidambaram and Asst. Professor, University College of Pharmaceutical Sciences,

Palamuru University, Mahabubnagar, Telangana, INDIA.

${ }^{2}$ Assistant Professor, Department of Pharmacy, FEAT, Annamalai University, Annamalai Nagar, Chidambaram, Tamilnadu, INDIA.

${ }^{3}$ Professor \& Principal, Joginpally B.R Pharmacy College, Yenkapally, Moinabad, R.R. Dist. Telangana, INDIA.

\section{Correspondence}

\section{GTharun}

PhD Research Scholar of Department of Pharmacy, Annamalai University,

Chidambaram and Asst. Professor, University College of Pharmaceutical Sciences, Palamuru University, Mahabubnagar, Telangana, INDIA

Phone no: +91 9866673808;

E-mail: tharun16goud@yahoo.com History

- Submission Date: 28-04-2020;

- Review completed: 25-05-2020;

- Accepted Date: 08-06-2020.

DOI : 10.5530/pj.2020.12.142

Article Available online http://www.phcogj.com/v12/i5

\section{Copyright}

(C) 2020 Phcogj.Com. This is an openaccess article distributed under the terms of the Creative Commons Attribution 4.0 International license.

\section{ABSTRACT}

Background: Cordia obliqua Willd plant is a genus of flowering plants in the borage family, Boraginaceae. It is also known as clammy cherry. Very little research was carried out for identification of its medicinal importance when compared to other Cordia species Objective: To determine the safe dose and to explore the in vivo antioxidant and hepatoprotective activity of Cordia obliqua fruits Methods: As per our previous study the ethanolic and aqueous extracts were rich in phytoconstituents and exhibited good in vitro antioxidant effect. So the ethanolic and aqueous extracts were used for evaluation of activity. Acute toxicity study $\left(L_{50}\right)$ was conducted according to OECD guidelines. For hepatoprotective activity paracetamol induced hepatotoxicity was studied using standard drug like Silymarin. The antioxidant potentiall of the plant extracts were tested using three tests viz, Reduced GSH, Catalase and SOD activity Results: Acute toxicity studies showed the non-toxic nature of Cordia obliqua fruit extract upto dose of $3000 \mathrm{mg} / \mathrm{kg}$ body weight. Administration of Paracetamol to rats increased the levels of marker enzymes like ALT, AST and ALP. Increase in the levels of these enzymes in serum indicates damage to the liver cells. Pretreatment with aqueous and ethanolic extracts of Cordia obliqua decreased the levels of ALT, AST, ALP and increased levels of total protein, total bilirubin, direct bilirubin and comparisons histology of cells of extract which are an indication for the hepatoprotective activity. Conclusion: The fruits of Cordia obliqua are safe and effective in treatment of hepatic disorders and prevent oxidation of cells.

Key words: Hepatotoxicity, Paracetamol, Silymarin, Cordia obliqua.

\section{INTRODUCTION}

Liver is the second largest and vital organ in the body which plays a vital role in metabolism and maintenance of homeostasis in human system. Toxic liver injury produced by drugs and chemicals are similar to natural liver disease. Continuous use of agents like Rifampicin, Isoniazid, Paracetamol, Ethyl alcohol, Carbon tetrachloride, Ranitidine and Oral contraceptives of hormonal origin and chemicals used as food preservatives and agrochemicals are threatening the integrity of liver. ${ }^{1,2}$ The effects of liver disease on hepatic metabolism of drugs are complex and difficult to predict, particularly when multiple drugs are administered simultaneously. ${ }^{3}$ Undiscerning use of anti-malarial drugs ${ }^{4}$, Anti-tubercular drugs ${ }^{5}$, analgesics, oral contraceptives ${ }^{6}$, Pharmaceuticals (mainly antibiotics, chemotherapeutics and CNS active drugs). ${ }^{7}$ Toxins in food (especially aflatoxin ${ }^{8}$, Viruses, bacteria, mushrooms, parasites like amoebas etc. may also infect the liver. ${ }^{9}$ According to American Gastroentorogical institutes official journal "Gastroenterology" recent survey has reported that they are $13 \%$ deaths has reported due to antibiotics and stated has "Idiosyncratic Drug Induced Liver Injury".

Herbal plants which contain wide variety of phytoconstituents which acts as a protective barrier for the liver and includes-monoterpenes, terpenoids, flavonoids, phenolic compounds, carotenoids, alkaloids, glycosides, organic acids, lipids ${ }^{10}$ Several Indian medicinal plants have been extensively used in the Indian traditional system of medicine for the management of liver disorders. In India over 40 polyherbal commercial formulations reputed to have hepatoprotective action is being used. Scrutiny of the literature indicates that 160 phyto-constituents from 101 plants belonging to 52 plant families have antihepatotoxic activity. ${ }^{11}$

In the present study, the fruits of Cordia obliqua were selected for evaluation of pharmacological activity and to identify the chemical constituents. Cordia obliqua Willd plant is a genus of flowering plants in the borage family, Boraginaceae. It contains about 300 species of shrubs and trees, which are found worldwide, mostly in warmer regions. It is a medium-sized deciduous tree and very vigorous in growth. Many of the species are commonly called manjack, Clammy Cherry, glue berries, sebesten, or snotty gobbles. According to traditional system, it possesses anthelmintic, purgative, diuretic, expectorant, antipyretic, hepatoprotective and analgesic action. The fruits are edible and used as pickle, vegetable, raw, cooked. They lessen thirst and the scalding of the urine, remove pain from the joints and the burning of the throat and are also effective in treating the diseases of the spleen. ${ }^{12}$ It was found that fruits are traditionally used for the treatment of hepatic disorders. ${ }^{13,14}$

The leaves of Cordia obliqua were investigated for hepatoprotective..$^{15}$ Analgesic, antipyretic and antiinflammatory activities. ${ }^{16}$ Since the fruits were

Cite this article: Tharun G, Sivakrishnan S, Sharma JVC. Toxicity Assessment, Evaluation of Antioxidant and Hepatoprotective Activity on Cordia obliqua Fruit Extracts. Pharmacogn J. 2020;12(5):1005-11. 
not investigated and reported for its hepatoprotective activity, this prompted us to select the fruits of Cordia obliqua.

\section{MATERIALS AND METHODS}

\section{Collection and authentification of plant}

Cordia obliqua fruits were collected from Chidambaram in month of September, herbarium was prepared \& submitted. Identification (Specimen voucher- HPU:102/2019) has been done by $\operatorname{Dr} P$ Shivakumar Singh, Head Department of Botany, Palamuru University, Mahabubnagar, Telangana, India.

\section{Preparation of extracts}

The fruits of Cordia were collected; shade dried, segregated, pulverized by a mechanical grinder and passed through a 40 mesh sieve. The powdered plant materials were stored in an air-tight container. Extraction of dried coarse powder of fruits was carried out by Soxhlet apparatus with different solvents such as Petroleum ether, Benzene, Chloroform, Acetone, Ethanol and finally macerated with Chloroform water by increasing order of polarity. The solvents were evaporated under reduced pressure to get semisolid masses and placed in desiccator for further use. The percentage yield of ethanol and water extract was found 12.76 and $34.78 \mathrm{w} / \mathrm{w}$ and it was dark brown in color. As per our previous studies the ethanolic and water extracts has exhibited in vitro antioxidant activity due to maximum number of Phyto-constituents as well as maximum total phenol content. So, the ethanol and aqueous extracts were selected for screening of biological activity.

\section{Preliminary phytochemical screening}

Several phytochemical tests were performed for testing different chemical groups present in the extracts. The chemical tests for various phytoconstituents present in the extracts were carried out as described. Alkaloids were tested by Mayer's, Wagers, Hager's and Dragendroffs reagent, phenols were identified by lead acetate and ferric chloride solution, saponins by foam test, steroids were identified by LibbermannBurchard and Salkowski test, cardiac glycosides by keller-kilianis and legal's test, tannins by ferric chloride solution, Sugars were identified by Molischs and Fehling's reagent, glycosides by acid hydrolysis followed by Molischs test. ${ }^{17-19}$

\section{Experimental animals}

Wistar rats of either sex with 8-12 weeks age, weighing 120-140g, were procured from the Sai Nath agency, Hyderabad, Telangana, India. The animals were set aside in cages, 2 per cage, with twelve: twelve hours light and dark cycle at $25 \pm 2{ }^{\circ} \mathrm{C}$. The rats were maintained on their particular diets and water ad libitum. All experimental Procedure done with standard procedure prescribed by CPCSEA, India and protocol approved by Institutional Ethical Committee with IAEC/COP/1920/02).

\section{Chemicals and drugs}

The chemicals used in study were Silymarin and Paracetamol which were collected from Micro labs, Bangalore. 2-thiobarbituric acid and Ellman's reagent was purchased from Sigma Aldrich, Bangalore. All other solvents and chemicals of all the drugs and chemicals used were of Pharmaceutical grade.

\section{Determination of acute oral toxicity $\left(\mathrm{LD}_{50}\right)$}

The acute oral toxicity study ${ }^{20}$ of fruit extracts of Cordia obliqua was determined in female albino mice (120-140 g) maintained under standard husbandry conditions. The animals were fasted $4 \mathrm{~h}$ prior to the experiment and Up and Down procedure (OECD Guidelines No. 425) method was adopted for acute oral toxicity studies. Animals were administered with single doses of each extract and observed for their physical behavior and mortality during $48 \mathrm{~h}$ study period (short term toxicity). Based on the short term profile of extracts the doses for the next animals were determined. All the animals were observed for long term toxicity ( 7 days). The $\mathrm{LD}_{50}$ studies of the test extracts were conducted with $180 \mathrm{mg} / \mathrm{kg}$ and use dose progression factor 3.2 single animals dose till body weight change or mortality and we met our criteria at dose level of $3000 \mathrm{mg} / \mathrm{kg}$ body weight.

\section{Paracetamol induced hepatotoxicity}

Wistar rats weighing between (120-140 g) were divided into five groups of six rats in each group. Group A was served as normal control which was given with vehicle only, Group B with Paracetamol $(2000 \mathrm{mg} / \mathrm{Kg}$ p.o), Group C with Silymarin ( $25 \mathrm{mg} / \mathrm{Kg}$ p.o) that serves as standard, Animals in groups D, E treated with $300 \mathrm{mg} / \mathrm{kg}$ of aqueous and ethanolic extracts respectively. B, C and D were intoxicated with Paracetamol ( $2 \mathrm{gm} / \mathrm{Kg}$ p.o) for 3 days and from $4^{\text {th }}-10^{\text {th }}$ day with different doses of Cordia obliqua in related groups respectively. On the $11^{\text {th }}$ day, after recording thiopentone sodium sleeping time in all groups of animals and they were anaesthetized with ether. Blood was collected through cardiac puncture, later sacrificed by overdose of ether. Livers removed were washed with saline, weighed and stored in $10 \%$ Formaldehyde for histological studies. ${ }^{21}$

\section{Histopathological studies}

For light microscopic evaluation, liver tissues were fixed in $10 \%$ buffered formalin and then thin sections $(4 \mu \mathrm{m})$ were subsequently stained with hematoxylin/eosin for general histological features determination. ${ }^{22}$ Sections were studied under light microscope Leica DM 500.

\section{In Vivo antioxidant activity on paracetamol induced hepatotoxicity in rats}

The antioxidant potential of the plant extracts were tested using three tests viz, Reduced GSH, Catalase and SOD activity. Accurately weighed $1 \mathrm{~g}$ of the liver tissue was taken and homogenized in $9 \mathrm{ml}$ of $1.15 \% \mathrm{KCl}$ with a Homogenizer. After successful homogenization, homogenized liver was kept in a freezer until it got frozen and later kept at room temperature to become liquefied. The same procedure was repeated for two freeze-thaw cycles. The homogenated liver was centrifuged at 3000 $\mathrm{rpm}$ at $4^{\circ} \mathrm{C}$ for $30 \mathrm{~min}$. The supernatant of the liver homogenate was separated and used for assays. The activity of GSH and Catalase was determined by the method of Sinha ${ }^{23}$ and Superoxide dismutase (SOD) activity by Markuland. ${ }^{24}$

\section{Statistical analysis}

The obtained values in all five groups were expressed as mean with SD from 6 animals, subjected to statistical analysis using one-way analysis of variance followed by Dunnett's $t$ test to verify significant difference if any among the groups. $P<0.05^{\star}, 0.01^{* *}$, and $0.001^{* * *}$ was considered statistically significant.

\section{RESULTS}

\section{Preliminary phytochemical analysis}

Preliminary phytochemical investigation of Cordia obliqua fruit extracts was carried out in our previous study to identify different primary and secondary metabolites. Petroleum ether, benzene, chloroform and acetone extracts showed the presence of steroids and cardiac glycosides; alkaloids in ethanolic extract, saponin; phenols and tannins in ethanolic and aqueous extracts, carbohydrates in chloroform, acetone, ethanolic and aqueous extracts, gums and mucilage in aqueous extract. 
The acute oral toxicity study of fruit extracts of Cordia obliqua

Acute toxicity studies showed the non-toxic nature of the Cordia obliqua fruit extract upto dose of $3000 \mathrm{mg} / \mathrm{kg}$ body weight which is 10 times more than the dose used in the study. The studies followed OECD guidelines. Based on the observation there was no change in physical behavior and mortality of any animals when observed for $48 \mathrm{hr}$. There was no lethality or any toxic reactions found at any of the doses selected until the end of the study period.

\section{Effect of aqueous and Ethanolic fruit extracts of Cordia obliqua on serum biochemical parameters}

ALT is an enzyme found in the liver that helps convert proteins into energy for the liver cells. When the liver is damaged, ALT is released into the bloodstream and levels increase. Aspartate transaminase (AST) is an enzyme that helps metabolize amino acids. Like ALT, AST is normally present in blood at low levels. An increase in AST levels may indicate liver damage, disease or muscle damage. Alkaline phosphatase (ALP). ALP is an enzyme found in the liver and bone and is important for breaking down proteins. Higher-than-normal levels of ALP may indicate liver damage or disease, such as a blocked bile duct, or certain bone diseases. Bilirubin is a substance produced during the normal breakdown of red blood cells. Bilirubin passes through the liver and is excreted in stool.

Elevated levels of bilirubin (jaundice) might indicate liver damage or disease or certain types of anemia. ${ }^{25}$ The serum levels of Aspartate aminotransferase (AST), Alanine aminotransferase (ALT) and alkaline Phosphatase (ALP) was significantly increased and the levels of total bilirubin, direct bilirubin and total protein were significantly decreased in paracetamol intoxicated rats when compared to normal control group (Tables 1 and 2). The group which received fruit extracts of
Cordia obliqua at $300 \mathrm{mg} / \mathrm{kg}$ body weight of both the extracts showed a significant increase in the mean levels of AST, ALT, ALP, TP, total bilirubin and direct bilirubin.

\section{Histopathology of liver}

In normal group (control) liver sections showed the normal lobular architecture of the liver (Figure1). Histological studies revealed that liver show moderate vacuolar degeneration, severe congested vessels. (Paracetamol) (Figure2). Histology of liver showed no micro vascular fatty changes and mild central venous congestion.(Sylimarin) (Figure3). In this group mild perivascular edema, moderate inflammatory cell infiltration was observed, (Ethanolic Extract) (Figure 4). Liver section showed very mild perivascular edema and very mild vacuolar degeneration and hemorrhage (Aqueous Extract) (Figure 5).

\section{In Vivo antioxidant activity on paracetamol induced hepatotoxicity in rats}

The activities of GSH, SOD and CAT in liver were significantly lower in Paracetamol induced hepatotoxicity rats compared to control rats. Administration of Cordia obliqua fruit extract at both doses showed a significant increase in GSH, SOD and CAT activity when compared to paracetamol intoxicated group. The in vivo antioxidant assay showed that the extract increased the activity of serum superoxide dismutase (SOD) and catalase and glutathione (GSH). Catalase is a ubiquitous enzyme that catalyzes the decomposition of hydrogen peroxide, a reactive oxygen species, which is a toxic product of both normal aerobic metabolism and pathogenic ROS production. ${ }^{26,27}$

The SOD catalyzes the dismutation of superoxide to hydrogen peroxide and oxygen, thereby reducing the likelihood of superoxide anion reacting with nitric oxide to form reactive peroxynitrite. ${ }^{27}$ Glutathione is largely known to minimize the lipid peroxidation of

\section{Table 1: Paracetamol Induced hepatotoxicity in fruit extract of Cordia obliqua.}

\begin{tabular}{|c|c|c|c|c|c|c|c|}
\hline S.No & Direct bilirubin & $\begin{array}{c}\text { Total } \\
\text { Bilirubin }\end{array}$ & $\begin{array}{c}\text { Total } \\
\text { Protein }\end{array}$ & Albumin & ALP & ALT & AST \\
\hline Normal & $0.72 \pm 0.29$ & $1.19 \pm 0.16$ & $6.52 \pm 1.07$ & $5.15 \pm 0.76$ & $41.6 \pm 3.64$ & $14.91 \pm 2.52$ & $59.38 \pm 3.51$ \\
\hline $\begin{array}{l}\text { Paracetamol } \\
\text { intoxicated } \\
2000 \mathrm{mg} / \mathrm{kg}\end{array}$ & $0.74 \pm 0.19$ & $1.14 \pm 0.22$ & $4.78 \pm 0.29$ & $3.16 \pm 0.48$ & $100.2 \pm 8.34$ & $40.8 \pm 1.82$ & $94.44 \pm 4.91$ \\
\hline $\begin{array}{c}\text { Standard } \\
\text { Slymarin treated } \\
25 \mathrm{mg} / \mathrm{kg}\end{array}$ & $0.74 \pm 0.05^{*}$ & $0.86 \pm 0.20^{*}$ & $8.20 \pm 0.05$ & $4.66 \pm 0.27^{\star}$ & $57.6 \pm 8.44^{*}$ & $25.26 \pm 1.95^{\star}$ & $65.8 \pm 3.49^{*}$ \\
\hline $\begin{array}{c}\text { Alcoholic extract } \\
300 \mathrm{mg} / \mathrm{kg}\end{array}$ & $1.25 \pm 0.12^{*}$ & $2.8 \pm 0.13^{\star}$ & $8.09 \pm 0.08^{\star}$ & $5.02 \pm 0.05$ & $79 \pm 3.93^{*}$ & $32.97 \pm 3.74^{*}$ & $78.8 \pm 8.18^{\star}$ \\
\hline $\begin{array}{l}\text { Aqueous extract } \\
300 \mathrm{mg} / \mathrm{kg}\end{array}$ & $1.23 \pm 0.13^{*}$ & $2.74 \pm 0.19^{*}$ & $9.03 \pm 0.8^{*}$ & $5.42 \pm 0.62^{*}$ & $64.2 \pm 3.89^{*}$ & $22.35 \pm 2.96^{*}$ & $63.22 \pm 6.48^{\star}$ \\
\hline
\end{tabular}

All Values are expressed as mean $\pm \operatorname{SEM}(\mathrm{n}=6)$, One Way Analysis of Variance. The result was significant at $p<.05$. ${ }^{*}$ Data differed significantly at $p<0.05$ when compared with the Paracetamol intoxicated group in the relevant column.

Table 2: Effects on liver antioxidant enzymes level in Paracetamol induced hepatotoxicity in rats.

\begin{tabular}{|c|c|c|c|}
\hline S.No & GSH ( $\mu \mathrm{g} / \mathrm{mg}$ protein) & CAT ( $\mu$ moles $\mathrm{H}_{2} \mathrm{O}_{2} / \mathrm{min} / \mathrm{mg}$ protein) & SOD (Unit/mg protein) \\
\hline Normal & $1.97 \pm 0.15$ & $4.06 \pm 0.26$ & $2.11 \pm 0.20$ \\
\hline $\begin{array}{l}\text { Paracetamol intoxicated } \\
2000 \mathrm{mg} / \mathrm{kg}\end{array}$ & $0.90 \pm 0.44$ & $1.19 \pm 0.47$ & $0.37 \pm 0.07$ \\
\hline $\begin{array}{c}\text { Standard } \\
\text { Slymarin treated } \\
25 \mathrm{mg} / \mathrm{kg}\end{array}$ & $1.74 \pm 0.84^{*}$ & $3.83 \pm 0.46$ & $1.86 \pm 0.16^{*}$ \\
\hline $\begin{array}{l}\text { Alcoholic extract } \\
300 \mathrm{mg} / \mathrm{kg}\end{array}$ & $1.58 \pm 0.38^{*}$ & $3.18 \pm 0.21^{*}$ & $1.07 \pm 0.12^{*}$ \\
\hline $\begin{array}{l}\text { Aqueous extract } \\
300 \mathrm{mg} / \mathrm{kg}\end{array}$ & $1.39 \pm 0.13^{*}$ & $2.51 \pm 0.20^{*}$ & $0.94 \pm 0.35^{\star}$ \\
\hline
\end{tabular}

All Values are expressed as mean $\pm \operatorname{SEM}(\mathrm{n}=6)$, One Way Analysis of Variance. The result was significant at $p<0.05$

*Data differed significantly at $p<0.05$ when compared with the Paracetamol intoxicated group in the relevant column. 


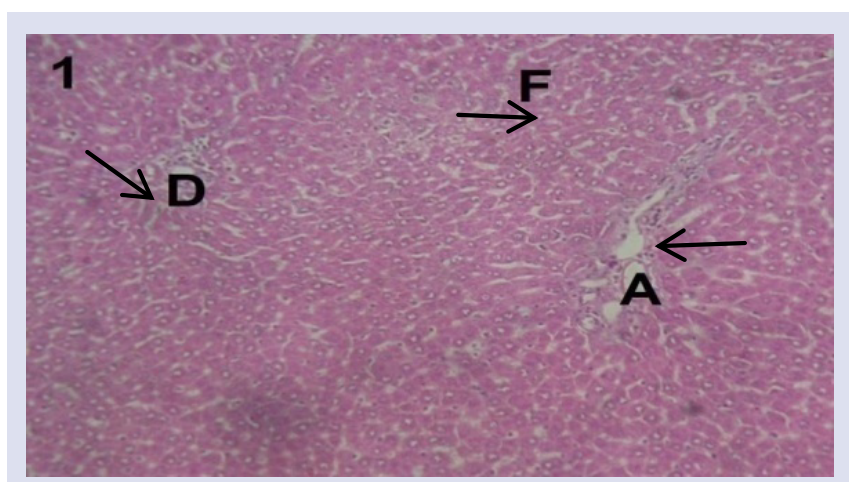

Figure 1: Histology of normal hepatic tissue.

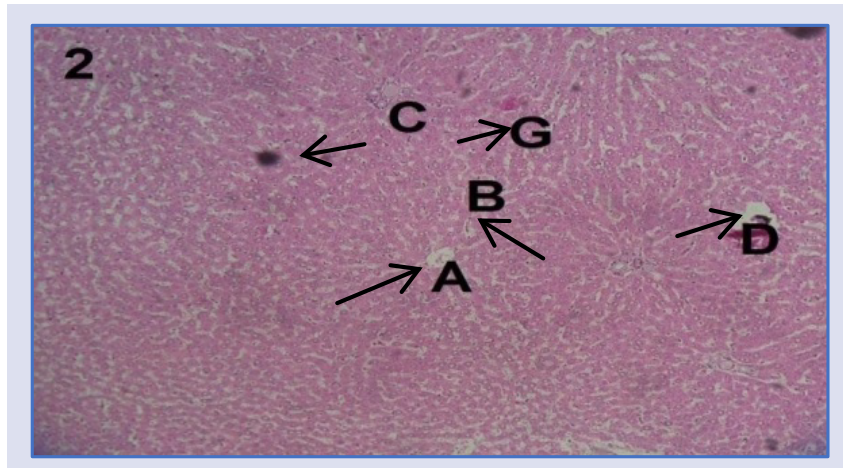

Figure 2: PCM induced damage in hepatic tissue.

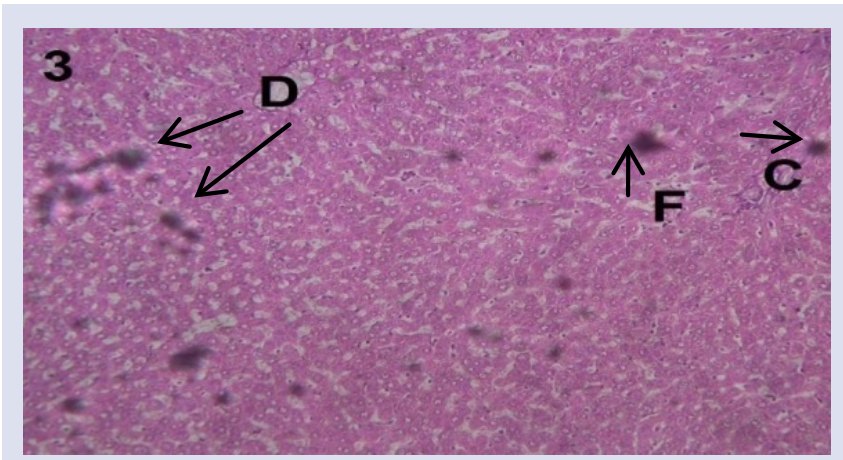

Figure 3: Effect of Silymarin on PCM induced hepatic damage.

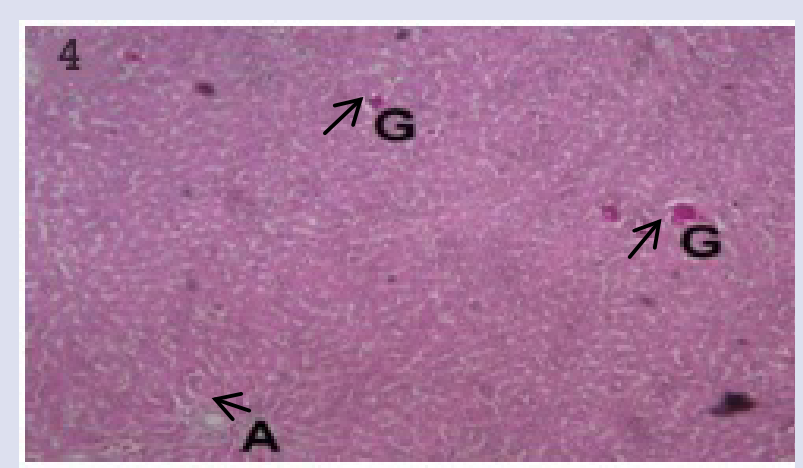

Figure 4: Effect of Cordia obliqua Ethanolic fruit extract on PCM induced hepatic damage.

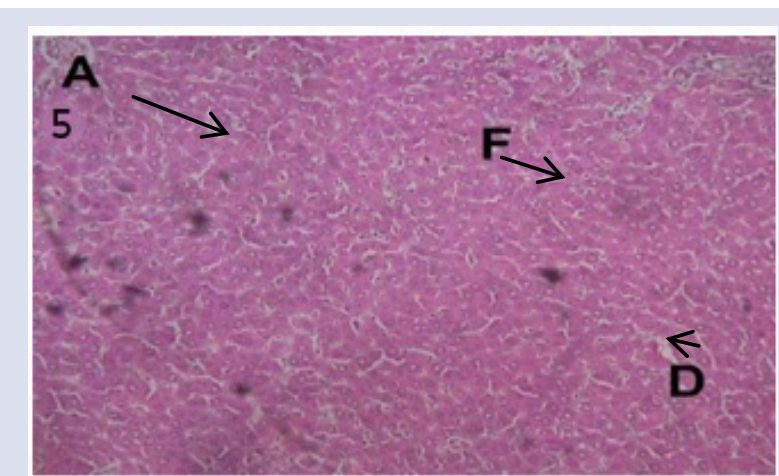

Figure 5: Effect of Cordia obliqua aqueous fruit extract PCM induced hepatic damage.

A: Central Vein, B: Total Degeneration, C: Sinusoids, D: Portal Triad, E: Portal Inflammation, F: Plates of Hepatocytes, G: Pyknosis

cellular membranes and other such targets that is known to occur with oxidative stress. $\mathrm{N}$-acetyl-cysteine is a by-product of glutathione and is popular due to its cysteine residues and the role it has on glutathione maintenance and metabolism. ${ }^{28}$

The increased serum activities of Catalase, GSH and SOD as observed in this study suggest that the extract has an in vivo antioxidant activity and is capable of ameliorating the effect of ROS in biologic system..$^{29,30}$

\section{DISCUSSION}

The study was carried out to evaluate the hepatoprotective and in vivo antioxidant activity of both aqueous and ethanolic fruit extracts of Cordia obliqua in paracetamol induced hepatotoxicity in Wistar Albino Rats. The results of present study showed that the extracts safe dose was $3000 \mathrm{mg} / \mathrm{kg}$. Liver injury is manifested in terms of increase in levels of serum aminotransferases, modest hepatic infiltration by both lymphocytes and eosinophils and slight focal hepatocellular necrosis also causes liver cholestasis associated with increased plasma bilirubin and alkaline Phosphatase. Paracetamol is a non-steroidal anti-inflammatory drug (NSAID), most commonly indicated in fever and mild to moderate pain like headache and myalgia. It is one of the safest NSAID in therapeutic dose and is well tolerated. PCM induces liver injury through the action of its toxic metabolite, N-acetyl-pbenzoquinone imine, produced by the action of Cytochrome P-450. Depletion of GSH causes the remaining quinone to bind to cellular macromolecules leading to cell death. Damage induced in the liver is accompanied by the increase in the activity of some serum enzymes. However, toxic doses of paracetamol cause severe hepatotoxicity characterized by abnormality of hepatic function and degeneration, necrosis or apoptosis of hepatocytes that leads to liver failure in both human and animals. Paracetamol has been taken as test model to screen the anti-hepatotoxicity of indigenous drugs.

In the present study it was observed that Chronic administration of Paracetamol to rats increased the levels of marker enzymes like ALT, AST and ALP as these are stored in the liver cells and increase in the levels of these marker enzymes in serum indicate damage to the liver cells. Pretreatment with aqueous and ethanolic fruit extracts of Cordia obliqua decreased the levels of ALT, AST, ALP and increased levels of total protein, total bilirubin and direct bilirubin is an indication for the hepatoprotective activity of these extracts against drug induced hepatotoxicity. 


\section{CONCLUSION}

The acute toxicity assessment revealed the safe dose of fruits and evaluated the hepatoprotective property of Cordia obliqua fruit extracts in paracetamol induced oxidative stress and hepatotoxicity in rats. The study correlated the hepatoprotective activity of Cordia obliqua fruit extract in both the extracts,; both the extracts has showed better hepatoprotective activity and it may be due to the presence of Alkaloids, Phenols and Tannins which exhibited free radical-scavenging and antioxidant activities.

\section{ACKNOWLEDGEMENT}

The authors are grateful to Dr. S.K. Agrawal, department of pharmacology, Anwar ul Uloom College of Pharmacy, Hyderabad for providing all necessary assistance to carry out this research work.

\section{CONFLICTS OF INTEREST}

The authors have no conflicts of interest.

\section{REFERENCES}

1. Handa S S, Sharma A, Chakraborti K K. Natural products and plants as liver protecting drugs. Fitoterapia. 1986, 57:307-51.

2. Dienstag J L, Isselbacher K J, "Toxic and drug-induced hepatitis", Chapter 296 In Harrison's Principles of internal medicine. Braunwald E., et al., $15^{\text {th }}$ Edn, The McGraw-Hill Companies, Inc., 2001, Vol.2,1737-42.

3. Piper D.W. et al. "Gastrointestinal and Hepatic Diseases", Chapter 22 in Avery's Drug treatment. Speight T M, Holford N H G, $4^{\text {th }}$ Edn, Adis International Limited, New Zealand: 1997, 937pp.

4. Dass E E, Shah K K. "Paracetamol and conventional antimalarial drugs induced hepatotoxicity and its protection by methionine in rats", Indian J. Exp. Biol. 2000 1138-42.

5. Saraswathy S.D. et al., "Effect of Liv.100 against antitubercular drugs (Isoniazid, Rifampicin and Pyrazinamide) induced hepatotoxicity in rats", Indian J. Pharmacol. 1998; 30: 233-8.

6. Bhanwra S., Singh J., Khosla P. "Effect of Azadirachta indica leaf aqueous extract on paracetamol-induced liver damage in rats", J Physiol Pharmacol. 2000; 44(1):64-8

7. Davies D M. Ed., Textbook of adverse drug reactions, $3^{\text {rd }}$ Edn, Oxford University Press, New York: 1985,253-65.

8. Ikino, H. and Kiso, Y., Natural products for liver disease. In: Wagner, H., Hikino, H. and Farnsworth N.R., editors. Economic and medicinal plant research, Vol. 2, Academic press, London, 1988,39.

9. Sharma, S.K., Ali, M. and Gupta, J., In; Evaluation of Indian hepatoprotective drugs, Singh, S., Govil, J.N. and Singh, V.K., editors. Recent progress in medicinal plants. Vol-2, Stadium Press, Texas, 2003, 253.

10. Johnson-Fannin A M. "Hepatitis: Viral and drug induced", Chapter 27 In Textbook of therapeutics drug and disease management, Herfindal ET, Gourley D R. $6^{\text {th }}$ Edn, Williams and Wilkins, USA: 1996;543-4
11. Handa, S.S., Sharma, A. and Chakraborti, K.K., Fitoterapia, 1986,57,307.

12. Johnson-Fannin A M. "Hepatitis: Viral and drug induced", Chapter 27 In Textbook of therapeutics drug and disease management, Herfindal ET, Gourley D R. $6^{\text {th }}$ Edn, Williams and Wilkins, USA: 1996;543-4

13. Kirtikar K R, Basu B D. Indian medicinal plants, $2^{\text {nd }}$ edn, Periodical experts book agency. Delhi.1991; 2(2):1488

14. Kurian J C. Plants that heals, $7^{\text {th }}$ edn, Oriental Watchman publishing house, Pune.2004;1:30.

15. Sivakrishnan Sivagnanam and Pradeepraj Devarasu. "Hepatoprotective activity of Cordia obliqua against paracetamol-induced liver toxicity on wistar rats". Asian Journal of Pharmaceutical and Clinical Research, Vol. 12, no. 7, May 2019, pp. 149-52

16. Gupta R, Gupta GD. Toxicity Assessment and Evaluation of Analgesic, Antipyretic and Anti-Inflammatory Activities on Cordia obliqua Leaf Methanol Extract. Pharmacog J. 2017;9(6):856-61.

17. Dr.K.R.Khandelwal, Practical Pharmacognosy techniques and experiments, 18th edition, Nirali Prakashan 2007.149-60.

18. Dr.C.K.Kokate, Practical Pharmacognosy, $19^{\text {th }}$ edition Nirali Prakashan,2008,149-56.

19. Herin Sheeba D,Gracelina A,John Britto et.al,Qualitative and Quantiative Analysis of Phytochemicals in Five Pteris Species, IntJPharmaSci,2013V ol(1):105-7.

20. https://doi.org/10.1787/9789264071049-en

21. Kurian J C. Plants that heals, $7^{\text {th }}$ edn, Oriental Watchman publishing house, Pune.2004; $1: 30$

22. J. D. Bancroft and M. Gamble, Theory and Practice of Histological Techniques, Churchill Livingstone Publications, Edinburgh, UK, 2002.

23. Sinha AK, Colorimetric assay of Catalase, Anal Biochem. 1972 Jun; 47(2):389 94.

24. Marklund, S and Marklund, G. (1974). Involvement of the superoxide anion radical in the autoxidation of pyrogallol and a convenient assay for superoxide dismutase. European Journal of Biochemistry, 47:469-474.

25. Vagvala SH, O'Connor SD. Imaging of abnormal liver function tests. Clin Liver Dis (Hoboken). 2018 May; 11(5):128-134.

26. ]. R. Kohen and A. Nyska, "Oxidation of biological systems: oxidative stress phenomena, antioxidants, redox reactions, and methods for their quantification," Toxicologic Pathology, vol. 30, no. 6, pp. 620-650, 2002.

27. A. C. Maritim, R. A. Sanders, and J. B. Watkins III, "Diabetes, oxidative stress, and antioxidants: a review," Journal of Biochemical and Molecular Toxicology, vol. 17, no. 1, pp. 24-38, 2003.

28. Chad Kerksick and Darryn Willoughby “The Antioxidant Role of Glutathione and $\mathrm{N}$-Acetyl-Cysteine Supplements and Exercise-Induced Oxidative Stress" J Int Soc Sports Nutr. 2005; 2(2): 38-44.

29. G. Manonmani, V. Bhavapriya, S. Kalpana, S. Govindasamy, and T. Apparanantham, "Antioxidant activity of Cassia fistula (Linn.) flowers in alloxan induced diabetic rats," Journal of Ethnopharmacology, vol. 97, no. 1, pp. 39-42, 2005.

30. T. Bakirel, U. Bakirel, O. U. Keles “, S. G. Ulgen, and H. Yardibi, " "In vivo assessment of antidiabetic and antioxidant activities of rosemary (Rosmarinus officinalis) in alloxan-diabetic rabbits," Journal of Ethnopharmacology, vol. 116, no. 1, pp. 64-73, 2008. 


\section{GRAPHICAL ABSTRACT}

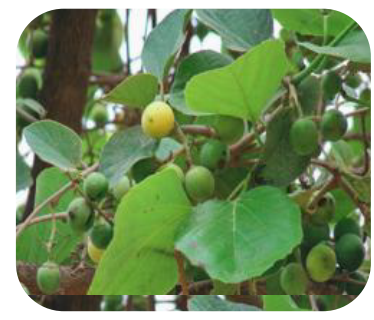

Fruit selection

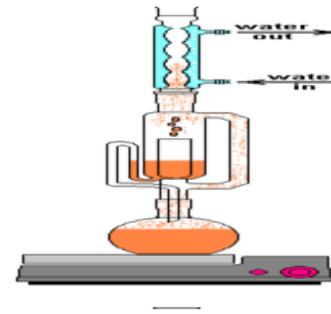

Extraction

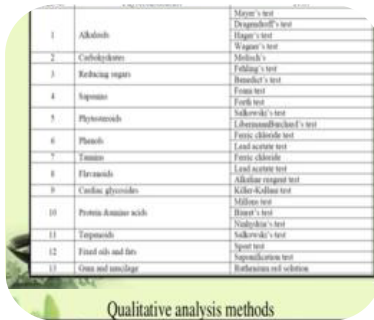

Phytochemical Screening

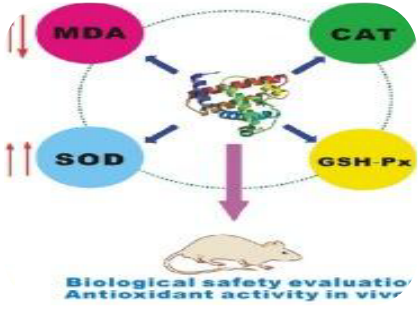

Estimation of Invivo Antioxidant acivity

\begin{tabular}{|c|c|c|c|}
\hline & & 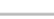 & \\
\hline- & Lhtows & custax & Lttan \\
\hline moneter & aweow & when & extary \\
\hline nembers & Lמнам" & whous & intarer \\
\hline resterente & 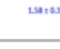 & santerent & Let aur \\
\hline mexte & Lm:ar & zstow & antas" \\
\hline
\end{tabular}

Effects on liver antioxidant enzymes level in Paracetamol induced hepatotoxicity in rats

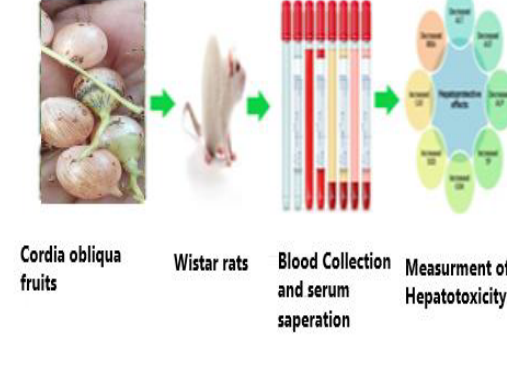

Evaluation of Hepatoproective acivity

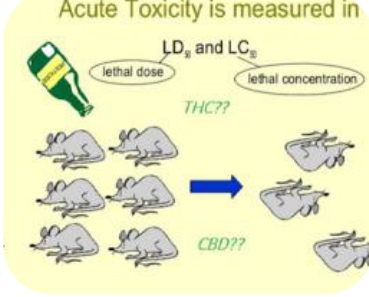

Toxicity assesment $3000 \mathrm{mg} / \mathrm{kg}$ body

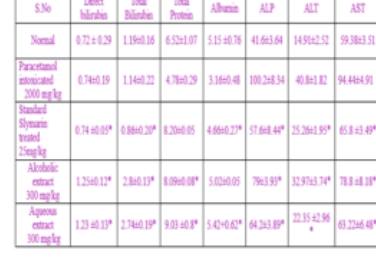

Paracetamol Induced hepatotoxicity in fruit extract of Cordia obliqua

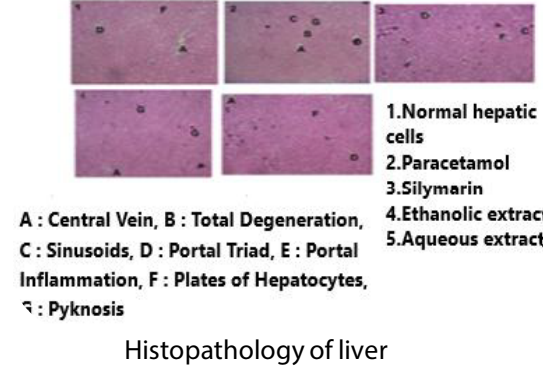

Histopathology of liver

\section{ABOUT AUTHORS}

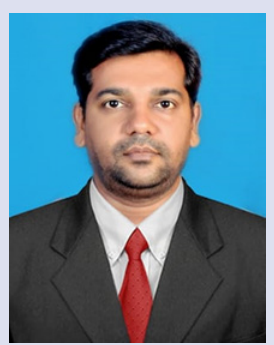

Mr.G.Tharun is Asst.Professor and Head Dept. Of Pharmacognosy, University College of Pharmaceutical Sciences, Palamuru University, Mahabubnagar, Telangana State. He received his Master's Degree in Pharmacognosy from Osmania University and perusing his PhD from Annamalai University. He has more than 11 years of teaching and research experience. He has authored 01 book and 04 book chapters. He has written more than 08 articles in leading journals and presented more than 17 research papers in national and international conferences. 


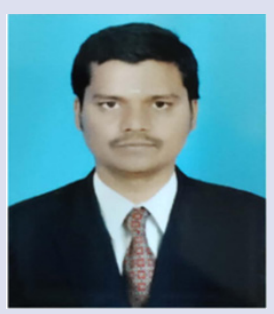

Dr.S.Sivakrishnan working as a Asst.Professor in Dept. Of Pharmacy, FEAT, Annamalai University, Annamalai Nagar, Chidambaram, Tamilnadu State. He received his Master's Degree in Pharmacology from Annamalai University and pursued his Ph.D from Annamalai University. He has more than 13 years of teaching and research experience. He has published more than 31 articles in indexed journals and presented more than 12 research papers in national and international conferences.

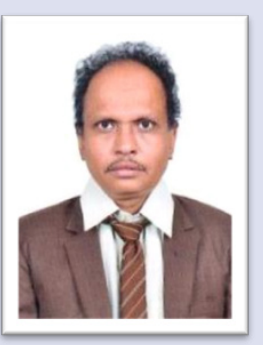

Dr.JVC.Sharma is Principal and Professor, in Joginpally B.R. Pharmacy College, Moinabad, Ranga Reddy Telangana State. He received his Ph.D Pharmaceutical sciences, Jawaharlal Nehru Technological University, Hyderabad. He has more than 22 years of teaching and research experience. Having five years of experience in abroad i.e. in K.S.A as a M. pharmacist and Clinical Pharmacologist in Dispensing and Compounding the medicines in Alwadh Hospital in Kingdom of Saudi Arabia and have qualified in examination conducted by Ministry of Health in K.S.A. for registered pharmacist. He has written more than 24 articles in leading journals and organized national and international conferences.

Cite this article: Tharun G, Sivakrishnan S, Sharma JVC. Toxicity Assessment, Evaluation of Antioxidant and Hepatoprotective Activity on Cordia obliqua Fruit Extracts. Pharmacogn J. 2020;12(5):1005-11. 